\title{
PERANCANGAN SISTEM INFORMASI INVENTORY DAN PENJUALAN MENGGUNAKAN VISUAL STUDIO
}

\section{Asep Ramdhany, Dena Irawan}

Sekolah Tinggi Manajemen Informatika dan Komputer (STMIK) Likmi Bandung Jawa

Barat, Indonesia

Email: dhanZ027@gmail.com, irawandena@gmail.com

\begin{abstract}
Abstrak
Sistem penjualan Handphone yang disediakan oleh Anis Cell yang sedang berjalan sekarang adalah masih secara manual didalam beberapa kegiatan-kegiatan atau proses-prosesnya yang antara lain adalah proses pengolahan data pelanggan, proses pengolahan data Handphone, proses pengolahan data transaksi, proses pengolahan data laporan. Tujuan dari penelitian ini adalah untuk mengetahui suatu proses yang ada dalam sistem dan siapa saja pelaku-pelaku yang terkait, serta untuk mengetahui apakah yang dihasilkan oleh suatu pihak sudah sesuai kebutuhan. Metode pengumpulan data yang dibuat dengan cara observasi, wawancara, dan studi literatur atau kajian pustaka yang memiliki relevansi erat dengan pokok permasalahan yaitu sistem yang dibuat bernama sistem informasi penjualan Handphone. Hasil penelitian ini menunjukkan bahwa sistem yang dibuat untuk lebih mengoptomatiskan sistem penjualan Handphone yang lama, menyimpan data dalam suatu basis data dan memberikan informasi penjualan dengan cepat dan tepat. Sistem Informasi Penjualan Handphone ini dibuat dengan Visual Studio 2008 dan SQL Server sebagai database. Perbaikan sistem informasi yang ada dengan menggunakan sistem informasi penjualan Handphone yang telah terkomputerisasi dan mengganti sistem yang sedang berjalan sekarang dengan sistem baru yang lebih cepat, efektif, dan efisien.
\end{abstract}

Kata Kunci: sistem informasi; inventaris; VB.NET 2008; MySQL

\section{Abstract}

Mobile sales system that is dikeder by Anis Cell which is currently running is still manually covered by activities or processes, among others, the process of processing data process process, process process transaction data, process data process report process. The purpose of this research is anything to know a process that exists in the system and who is doing which ones are related, and for which the results are who is the suitable party. How to collect data which by means of observation, images, and literature studies or literature studies that have close relevance to the main side of the system is the system that is the content of the Mobile Sales Information System. The results of this study showed that the system that teda to further optimize the old Mobile sales system, data that is sucked in the database and sales sales quickly and precisely. The Mobile Sales Information System is created with visual studio 2008 and sql server databases. The system that is dis-information that exists by using the

$\begin{array}{lll}\text { How to cite: } & \text { Ramdhany, Asep dan Dena Irawan (2021) Perancangan Sistem Informasi Inventory dan Penjualan } \\ & \text { Menggunakan Visual Studio. Syntax Literate: Jurnal Ilmiah Indonesia. } & \text { 6(7). } \\ & \text { http://dx.doi.org/10.36418/syntax-literate.v6i7.3518 } \\ \text { E-ISSN: } & 2548-1398 \\ \text { Published by: } & \text { Ridwan Institute }\end{array}$


existing mobile sales information system computerized and which system is running now with a new system that is faster, system and good.

Keywords: information systems; inventory; VB.NET 2008; MySQL

\section{Pendahuluan}

Perkembangan bisnis dan dalam penyedia informasi di internet atau website untuk pemilik bisnis dan penyedia informasi semakin memudahkan untuk menyajikan dan menyampaikan informasi kepada masyarakat luas. Namun, dalam proses bisnis di Anis Cell masih manual, dengan harapan suatu sistem yang komputerisasi akan menjadikan pekerjaan lebih efisien dan efektif di Anis Cell. Dengan demikian, akurasi pemrosesan data terutama saat membeli barang, mengganti barang, dan memantau penjualan yang sedang berjalan dapat dioptimalkan. Masalah yang sering terjadi adalah tidak akurat antara pengeluaran barang dan pemasukan barang untuk memudahkan dan menyediakan data yang akurat di Anis Cell (Lubis, 2016).

Menurut (Laila, 2011) "Pencarian barang di gudang akan lebih cepat dan efektif karena dalam setiap transaksi (pembelian atau penjualan) otomatis akan memperbarui persediaan, sehingga petugas gudang dapat lebih mudah memeriksa persediaan sebenarnya setiap saat. Dapat memberikan informasi yang diperlukan secara realtime, yang artinya akan membantu pimpinan dalam melihat progres perusahaan. Karena dengan adanya komputerisasi maka penyimpanan data akan selalu terkontrol dan terjaga keakuratannya, data dapat diperhitungkan sehingga informasi yang dihasilkan lebih akurat dan bermanfaat bagi yang membutuhkan. Laporan kesalahan data dapat diproses dengan mudah, sehingga setiap laporan dapat dikoreksi dengan cepat dan mudah kapan saja”.

Pengertian sistem informasi, Menurut (Boell \& Cecez-Kecmanovic, 2015) dalam jurnalnya memberikan penjelasan mengenai Sistem Informasi (SI) yang melibatkan berbagai Teknologi Informasi (TI) seperti komputer, database, sistem komunikasi dan internet untuk melakukan tugas-tugas secara khusus dengan memberikan informasi kepada pengguna dalam konteks organisasi atau sosial yang berbeda. (Aggraeni, Anandya, \& Margaretha, 2014), persediaan "Inventory adalah banyaknya bahan dan barang yang disediakan oleh perusahaan berupa produk jadi, bahan baku atau bahan dalam proses yang disediakan untuk menjaga kelancaran operasional perusahaan dan senantiasa memenuhi kebutuhan konsumen".

Analisa sistem sangat diperlukan demi kelancaran alur informasi yang dibutuhkan oleh segala bidang kehidupan baik bidang politik, hukum, pendidikan, ataupun ekonomi, khususnya dibidang perdagangan ini dengan itu kebutuhan akan informasi yang mudah diakses, cepat, dan akurat itu sangat dibutuhkan agar sistem bisa berjalan dengan baik (Uslamarta, 2019). Setelah melaksanakan observasi di Anis Cell, sistem informasi penjualan Handphone belum berjalan cukup baik, misalnya pada pengolahan data dan kegiatan transaksi masih menggunakan sistem yang manual yang disimpan dalam buku catatan khusus (Simarmata et al., 2020). 
Tujuan dari penelitian ini adalah untuk mengetahui suatu proses yang ada dalam sistem dan siapa saja pelaku-pelaku yang terkait, serta untuk mengetahui apakah yang dihasilkan oleh suatu pihak sudah sesuai kebutuhan.

\section{Metode Penelitian}

Metode penelitian yang digunakan dalam penelitian ini dinamakan SDLC (System Development Life Cycle), SDLC adalah beberapa proses yang saling berhubungan untuk membangun sistem, merancang sistem, membangun, dan menyampaikannya kepada pengguna. SDLC memiliki beberapa model yang telah dikembangkan berdasarkan prinsip SDLC tergantung pada sistem yang akan diterapkan.

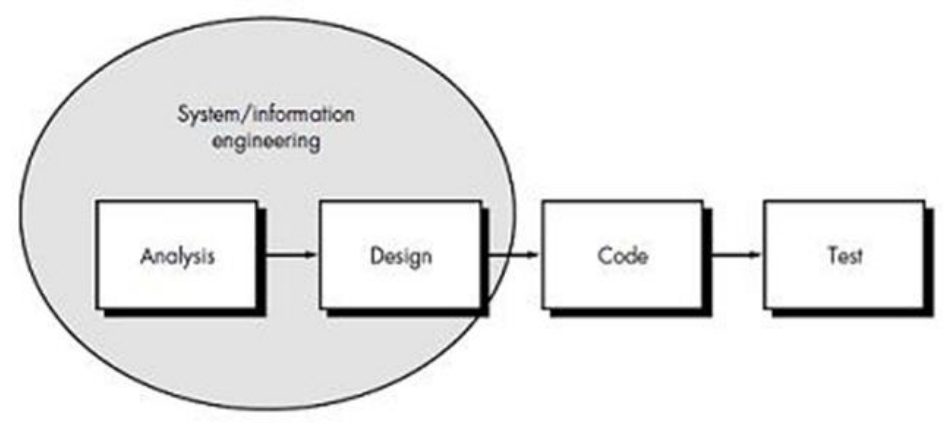

\section{Gambar 1}

Model Waterfall

Sumber: (Roger \& Bruce, 2015), Software Engineering

\section{Hasil dan Pembahasan}

\section{A. Analisa Kebutuhan}

Berikut adalah analisa kebutuhan dari sistem yang akan digunakan:

1. Use Case Diagram

a. Use Case Diagram dari Sistem

Use Case diagram adalah suatu diagram yang menggunakan notasi-notasi untuk menggambarkan arus dari data sistem yang penggunaanya sangat membantu untuk memahami sistem secara logika, terstruktur, dan jelas. Adapun Use Case diagram untuk sistem yang sedang berjalan sebagai berikut: 


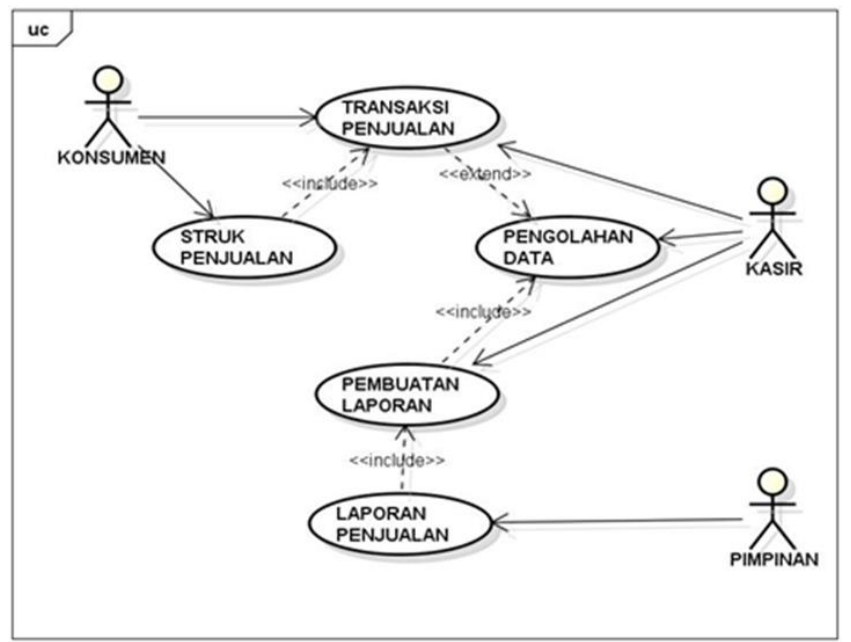

Gambar 2

Use Case Diagram Penjualan Handphone yang sedang Berjalan

(Gata \& Gata, 2013)

Skenario Use Case

1. Nama Use Case : Transaksi Penjualan

Aktor : Konsumen

Tujuan : Transaksi penjualan Handphone pada Excel.

Deskripsi : Konsumen melakukan transaksi penjualan kepada kasir untuk pembayaran Handphone yang telah jadi dibeli.

2. Nama Use Case : Struk Penjualan

Aktor : Konsumen

Tujuan : Mencetak Laporan Struk penjualan

Deskripsi : Konsumen menerima struk pembelian Handphone dari kasir kemudian kasir mengolahnya kedalam form penjualan.

3. Nama Use Case : Pengolahan Data

Aktor : Kasir

Tujuan : Mengolah laporan penjualan

Deskripsi : Kasir mengolah dan membuat laporan penjualan Handphone yang telah di beli oleh konsumen.

4. Nama Use Case : Pembuatan Laporan

Aktor : Kasir

Tujuan : Membuat laporan penjualan

Deskripsi : Kasir mengolah dan membuat laporan penjualan yang telah di beli oleh konsumen.

5. Nama Use Case : Laporan Penjualan

Aktor : Pimpinan

Tujuan : Menyerahkan Laporan penjualan

Deskripsi

a. Kasir akan memberikan laporan penjualan Handphone sesuai dengan yang telah di beli oleh konsumen.

b. Pimpinan menerima laporan Penjualan Handphone. 


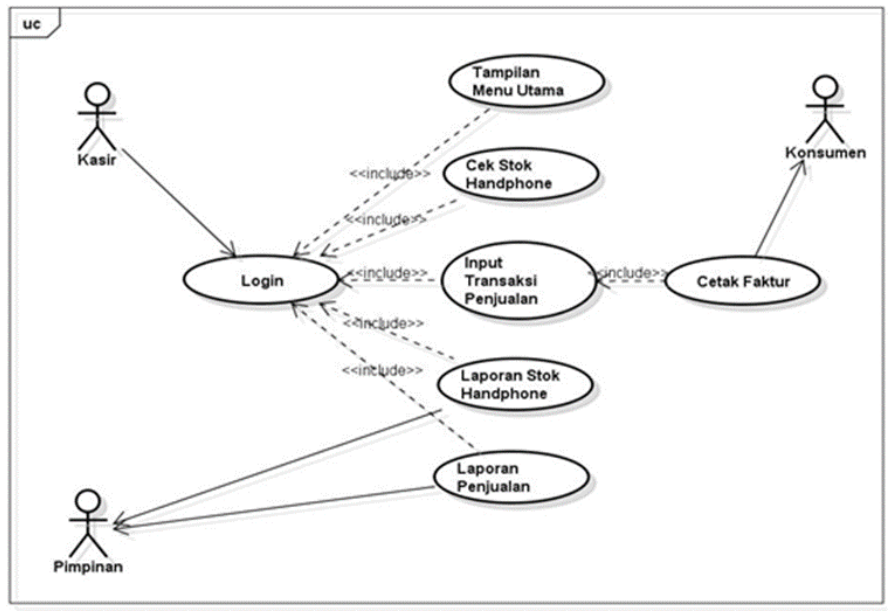

\section{Gambar 3}

Use Case Diagram Sistem

(Ramdhany \& Kurnia, 2016)

Skenario Use Case

Nomor : :01

Nama Use Case : Login

Aktor : Kasir

Tujuan : Menjelaskan proses inisialisasi User

Tabel 1

Penjelasan Skenario Use Case Login

(Noviandi, Fatimah, \& Partono, 2012)

Aktor

Sistem

User memasukan Username dan password Sistem melakukan verifikasi saat aplikasi sistem penjualan pelumas Username dan password yang telah mulai dioperasikan masuk kedalam database, jika benar maka User bisa mengakses sistem transaksi penjualan.

\section{Sumber: Penulis}

Tabel 2

Penjelasan Deskripsi Use Case Login

\begin{tabular}{cl}
\hline Use Case & \multicolumn{1}{c}{ Login } \\
\hline Aktor & Kasir \\
\hline Deskripsi & $\begin{array}{l}\text { User melakukan login dengan memasukan Username dan } \\
\text { password untuk masuk ke dalam sistem pengolahan } \\
\text { transaksi penjualan pelumas tersebut. }\end{array}$ \\
\hline Sistem & $\begin{array}{l}\text { Sistem melakukan verifikasi Username dan password yang } \\
\text { telah masuk kedalam database, jika benar maka User bisa } \\
\text { mengakses sistem transaksi penjualan. }\end{array}$ \\
\hline
\end{tabular}

Sumber: Penulis

Skenario Use Case

Nomor 


$\begin{array}{ll}\text { Nama Use Case } & \text { : Tampilan Menu Utama } \\ \text { Aktor } & \text { : Kasir } \\ \text { Tujuan } & \text { : Menjelaskan proses akses selenjutnya }\end{array}$

Tabel 3

Penjelasan Skenario Use Case Tampilan Menu Utama

\begin{tabular}{cl}
\hline Aktor & \multicolumn{1}{c}{ Sistem } \\
\hline Kasir & $\begin{array}{l}\text { 1. Sistem melakukan verifikasi Username dan password } \\
\text { yang telah masuk kedalam database, jika benar maka } \\
\text { User bisa mengakses sistem pada menu utama. }\end{array}$ \\
\hline $\begin{array}{l}\text { 2. User akan memilih proses atau kegiatan yang akan } \\
\text { dilakukan. }\end{array}$ \\
$\begin{array}{l}\text { 3. Sistem menyediakan atau memilih yang menghendaki } \\
\text { proses apa yang akan dilakukan oleh User. }\end{array}$ \\
\hline
\end{tabular}

Sumber: Penulis

Tabel 4

Penjelasan Deskripsi Use Case Tampilan Menu Utama

\begin{tabular}{cl}
\hline Use Case & \multicolumn{1}{c}{ Tampilan menu utama } \\
\hline Aktor & \multicolumn{1}{c}{ Kasir } \\
\hline Deskripsi & $\begin{array}{l}\text { Setelah User melakukan login, maka akan langsung pada } \\
\text { posisi menu utama yang bisa mengakses beberapa proses } \\
\text { lainnya. }\end{array}$ \\
\hline Sistem & $\begin{array}{l}\text { Sistem menyediakan atau memilih yang menghendaki } \\
\text { proses apa yang akan dilakukan oleh User. }\end{array}$ \\
\hline
\end{tabular}

Sumber: Penulis

Skenario Use Case

Nomor : 03

Nama Use Case : Cek Stok Handphone

Aktor : Kasir

Tujuan : Menjelaskan proses cek stok Handphone

Tabel 5

Penjelasan Skenario Use Case Cek Stok Handphone

Aktor Sistem

1.User mencari data barang yang 2. Sistem akan menampilkan data

dipilih oleh pelanggan untuk melihat Handphone tersebut

stok Handphone

Sumber: Penulis

Tabel 6

Penjelasan Deskripsi Use Case Input Data Pelanggan Use Case Cek Stok Handphone

Aktor Kasir

Deskripsi User mencari data Handphone pada database

Sistem Sistem menampilkan data Handphone tersebut 
Skenario Use Case

Sumber: Penulis

Nomor : :04

Nama Use Case : : Input Transaksi Penjualan

Aktor

: Staff dan Manajemen

Tujuan

: Menjelaskan proses penginputan transaksi penjualan

Tabel 7

Penjelasan Skenario Use Case Input Transaksi Penjualan

Aktor

Sistem

1. User memasukan data transaksi 2. Sistem akan menerima proses input penjualan kedalam sistem penjualan data transaksi penjualan dan akan Barang menyimpannya kedalam sistem penjualan spartpart.

Sumber: Penulis

\section{Tabel 8}

Penjelasan Deskripsi Use Case Input Transaksi Penjualan Use Case Input transaksi penjualan

Aktor Staff, Manajemen

Deskripsi User melakukng transaksi penjualan dengan menginaputkan data barang lalu jumlah dan harga

Sistem Sistem akan menyimpan data trnsaksi penjualan yang telah dilakukan kedalam database.

Sumber: Penulis

Skenario Use Case

Nomor $: 05$

Nama Use Case

: Laporan Stok Barang

Aktor

: Kasir

Tujuan

: Menjelaskan proses cetak laporan stok Handphone

Tabel 9

Penjelasan Skenario Use Case Laporan Stok Handphone

Aktor Sistem

1. User mencetak laporan stok 2. Sistem akan menerima proses cetak barang. laporan stok Handphone dan akan mencetak laporan stok Handphone.

Sumber: Penulis

Tabel 10

Penjelasan Deskripsi Use Case Update Data Handphone

\begin{tabular}{cl}
\hline Use Case & \multicolumn{1}{c}{ Laporan stok Handphone } \\
\hline Aktor & Kasir \\
\hline Deskripsi & $\begin{array}{l}\text { User melakukan cetak laporan stok Handphone yang } \\
\text { nanti nya akan diberikan kepada pemilik toko }\end{array}$ \\
\hline Sistem & Sistem mencetak laporan stok Handphone.
\end{tabular}

Sumber: Penulis 
Perancangan Sistem Informasi Inventory dan Penjualan Menggunakan Visual Studio

Skenario Use Case

$\begin{array}{ll}\text { Nomor } & : 06 \\ \text { Nama Use Case } & \text { : Laporan Penjualan } \\ \text { Aktor } & \text { : Kasir } \\ \text { Tujuan } & \text { : Menjelaskan proses cetak laporan penjualan }\end{array}$

Tabel 11

Penjelasan Skenario Use Case Update Data User

Aktor Sistem

1. User mencetak laporan 2. Sistem akan menerima proses penjualan. cetak laporan penjualan dan akan mencetak laporan penjualan.

Sumber: Penulis

Tabel 12

Penjelasan Deskripsi Use Case Update User

\begin{tabular}{cl}
\hline Use Case & \multicolumn{1}{c}{ Laporan Penjualan } \\
\hline Aktor & Kasir \\
\hline Deskripsi & $\begin{array}{l}\text { User melakukan cetak laporan stok Handphone yang } \\
\text { nanti nya akan diberikan kepada pimpinan }\end{array}$ \\
\hline Sistem & Sistem mencetak laporan penjualan. \\
\hline
\end{tabular}

Sumber: Penulis

b. Class Diagram

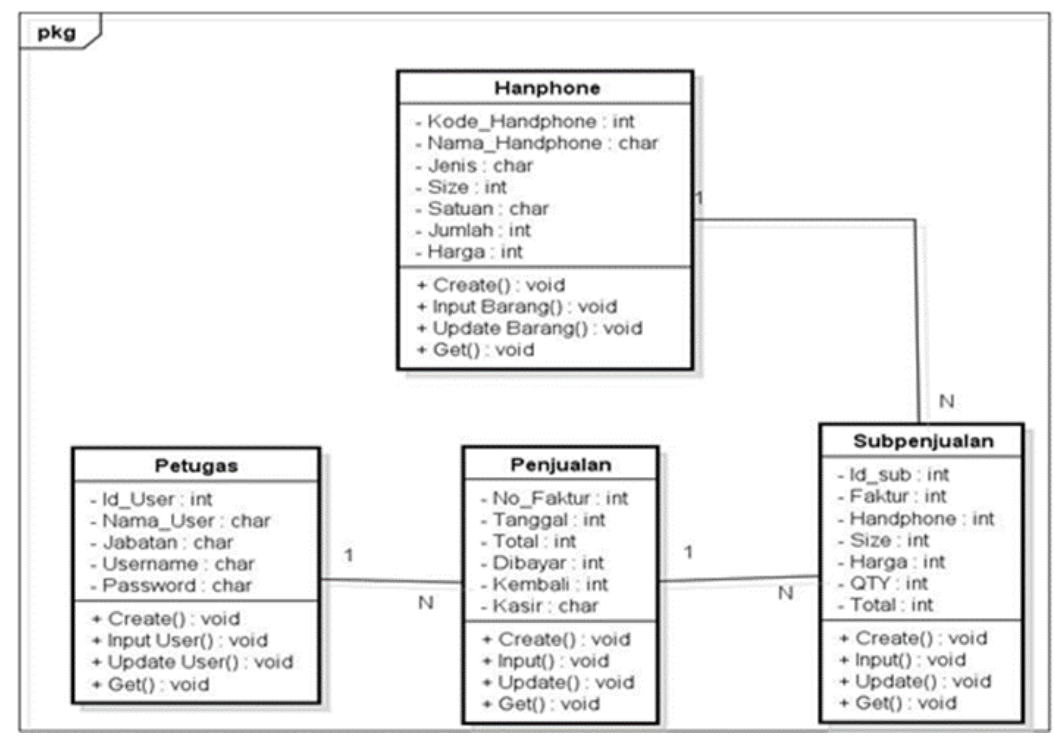

Gambar 4

Functional Design Class Diagram

(Rossa \& Shalahuddin, 2013) 
Tabel 13

Class Diagram Sistem Penjualan Handphone

\begin{tabular}{lc}
\hline No. & $\begin{array}{c}\text { Identifikasi } \\
\text { Class }\end{array}$ \\
\hline 1. & Petugas
\end{tabular}

1. Petugas Pengguna disini adalah User (kasir) yang akan mengoperasikan atau mempergunakan sistem informasi penjualan Handphone dalam transaksinya.

2. Sub Sub penjualan disini adalah database penampung sementara penjualan proses transaksi penjualan

3. Handphone Handphone adalah komoditi yang dijual atau dipakai.

4. Penjualan Penjualan adalah suatu usaha yang terpadu untuk mengembangkan rencana-rencana strategis yang diarahkan pada suatu pemesanan kebutuhan dan keinginan pembeli.

c. Activity Diagram

\section{Sumber: Penulis}

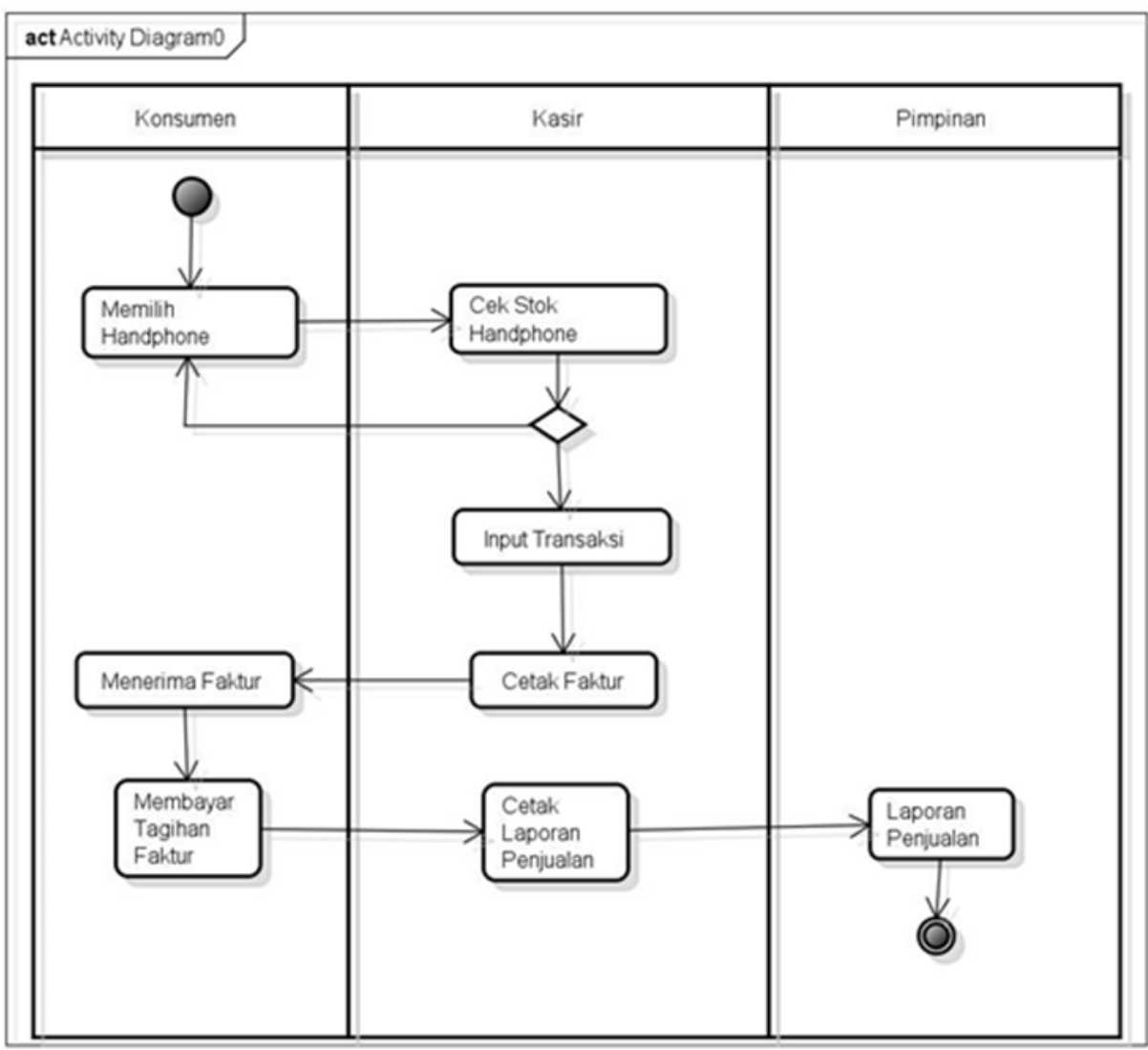

Gambar 4

Functional Activity Diagram

(Irsyad, 2014) 
Perancangan Sistem Informasi Inventory dan Penjualan Menggunakan Visual Studio

d. State Chart Diagram

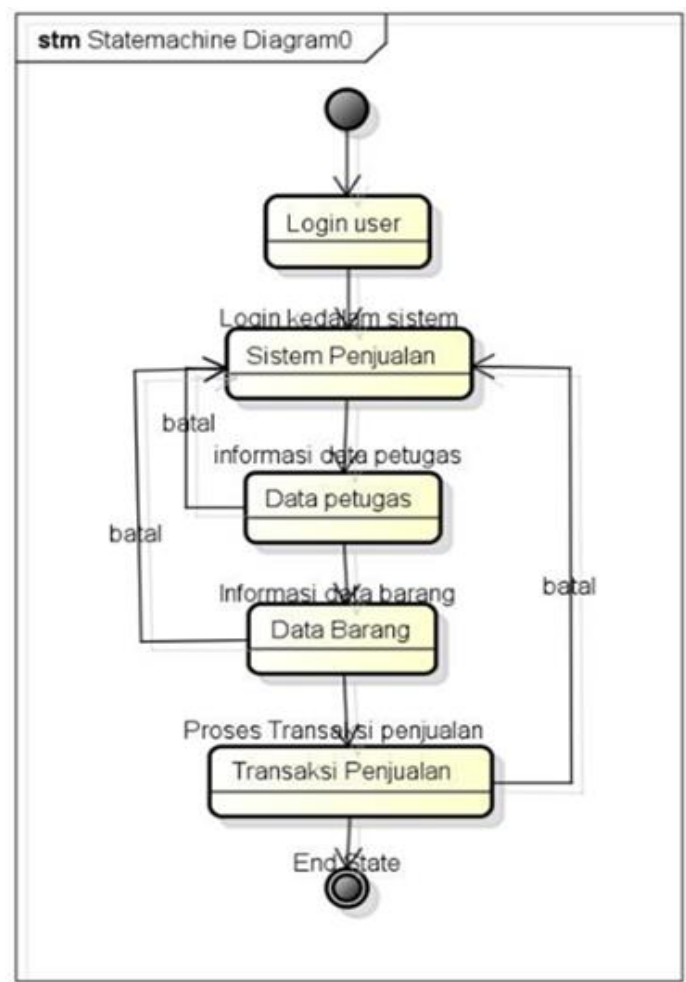

Gambar 5

Functional State Chart Diagram

(Solichin, 2010)

Tabel 14

Keterangan State Chart Diagram

\begin{tabular}{lcl}
\hline No. & Nama State & \multicolumn{1}{c}{ Keterangan } \\
\hline 1. & Login User & $\begin{array}{l}\text { User masuk login terlebih dahulu untuk masuk } \\
\text { kedalam sistem }\end{array}$ \\
\hline 2. & Sistem penjualan & $\begin{array}{l}\text { User sudah masuk dalam sistem untuk memulai } \\
\text { transaksi penjualan }\end{array}$ \\
\hline 3. & Data pelanggan & $\begin{array}{l}\text { User masuk kedalam form data pelanggan untuk } \\
\text { menginput data pelanggan }\end{array}$ \\
\hline 4. & Data Handphone & $\begin{array}{l}\text { User masuk kedalam form data Handphone untuk } \\
\text { menginput data Handphone }\end{array}$ \\
\hline 5. & Transaksi Penjualan & $\begin{array}{l}\text { User } \text { melakukan transaksi penjualan } \\
\text { Sumber: Penulis }\end{array}$ \\
\hline & & \\
\hline
\end{tabular}


Asep Ramdhany, Dena Irawan

e. Squence Diagram.

1. Squence Diagram Penjualan

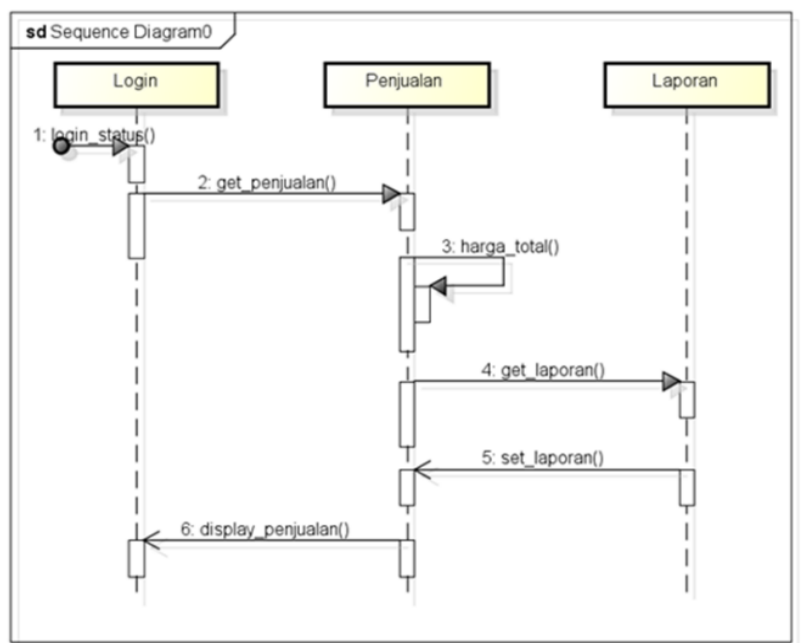

\section{Gambar 6}

Functional Squence Diagram Penjualan

(Tohari, 2017)

Tabel 15

Keterangan Sequence Diagram Penjualan

\begin{tabular}{lcl}
\hline No. & Nama Object & \multicolumn{1}{c}{ Keterangan } \\
\hline 1. & Login & login_status() \\
\hline 2. & Penjualan & get_penjualan(),harga_total(), display_penjualan() \\
\hline 3. & Laporan & get_penjualan(), set_laporan() \\
\hline
\end{tabular}

Sumber: Penulis

2. Squence Update Pelanggan

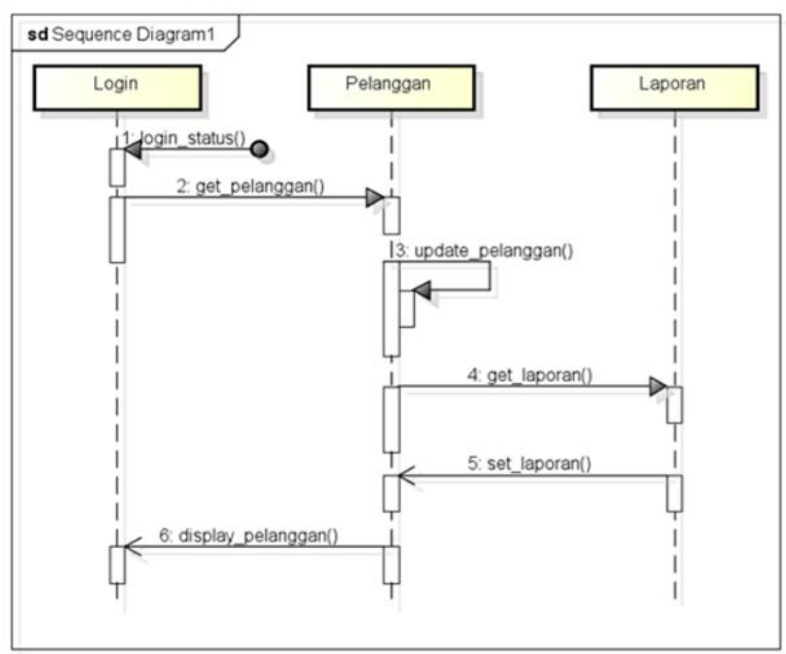

Gambar 7

Functional Squence Update Pelanggan

(Dharmawan \& Sari, 2016) 


\section{Tabel 16}

Keterangan Sequence Diagram Update Pelanggan

\begin{tabular}{ccl}
\hline No. & Nama Object & Keterangan \\
\hline 1. & Login & login_status() \\
\hline 2. & Pelanggan & get_pelanggan(), update_pelanggan(), display_pelanggan() \\
\hline 3. & Laporan & get_laporan(), set_laporan() \\
\hline \multicolumn{3}{c}{ Sumber: Penulis }
\end{tabular}

3. Squence Update Barang

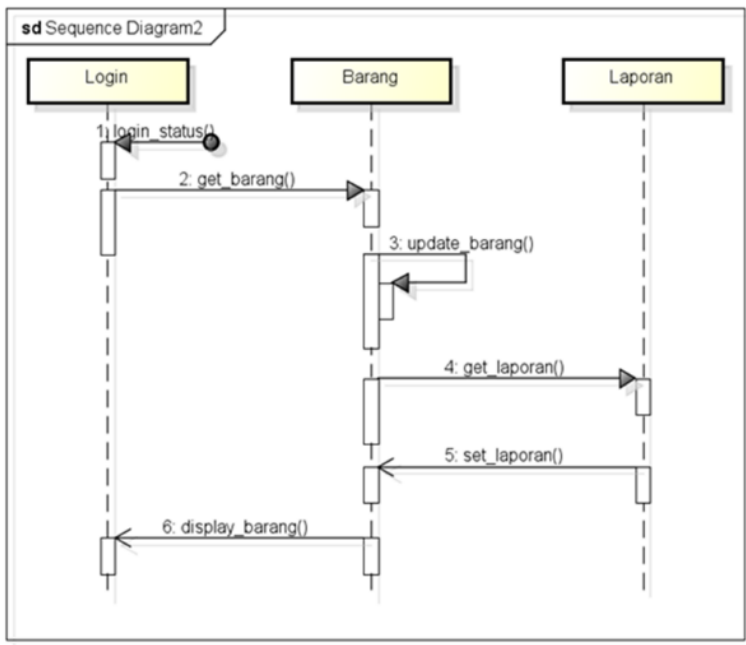

Gambar 8

Functional Squence Update Barang

Table 17

Keterangan Sequence Diagram Update Barang

\begin{tabular}{ccl}
\hline No. & Nama Object & \multicolumn{1}{c}{ Keterangan } \\
\hline 1. & Login & login_status() \\
\hline 2. & Barang & get_barang(), update_barang(), display_barang() \\
\hline 3. & Laporan & get_laporan(), set_laporan() \\
& & Sumber: Penulis
\end{tabular}

f. Communication Diagram

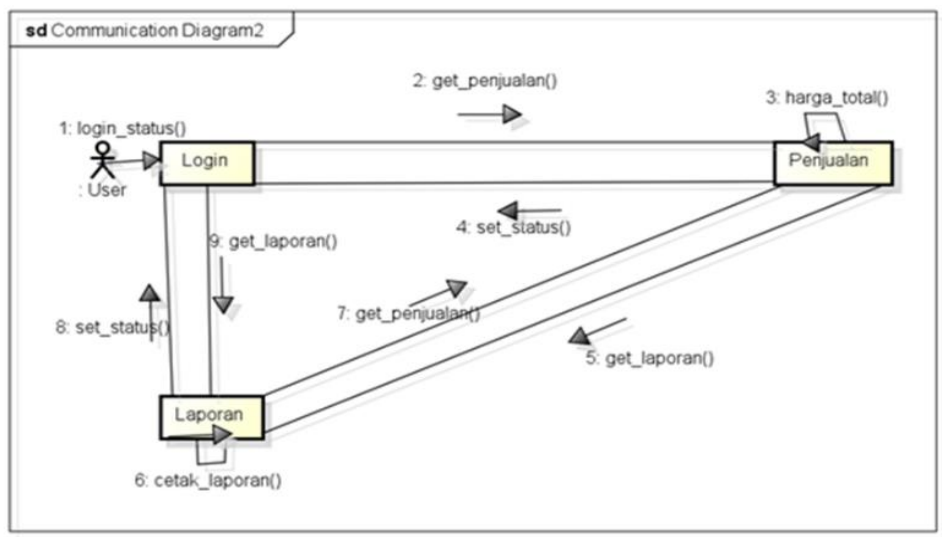

Gambar 9

Functional Communication Diagram Penjualan 
Tabel 18

Keterangan Communication Diagram Penjualan

\begin{tabular}{ccl}
\hline No. & Nama Object & \multicolumn{1}{c}{ Keterangan } \\
\hline 1. & Login & login_status() \\
\hline 2. & Penjualan & get_penjualan(),harga_total(), set_status(), get_laporan() \\
\hline 3. & Laporan & cetak_laporan(),get_penjualan(), set_ststus() \\
\hline & & Sumber: Penulis
\end{tabular}

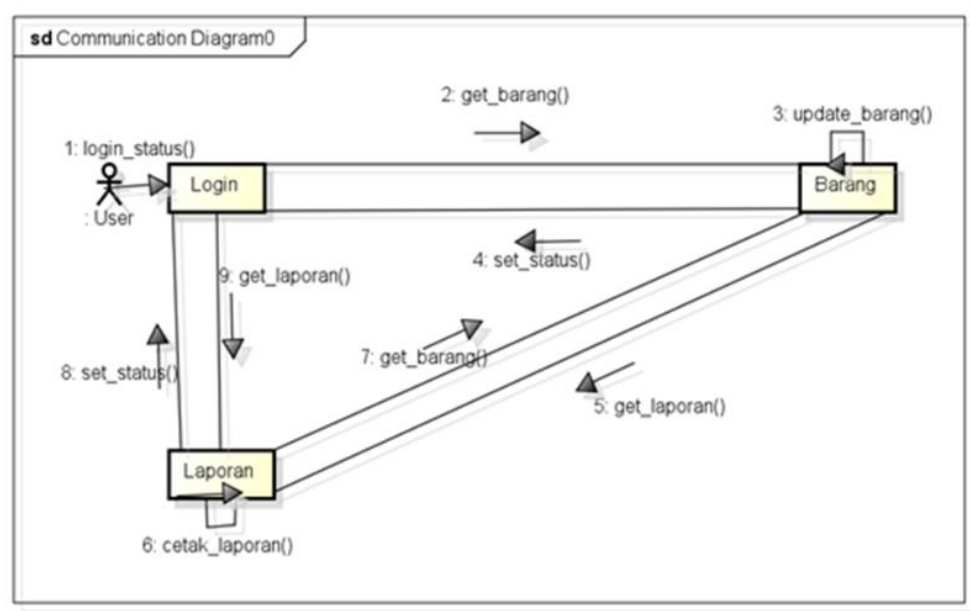

Gambar 10

Functional Communication Update Pelanggan

Tabel 19

Keterangan Communication Diagram Penjualan

No. Nama Object

1. Login login_status()

2. Penjualan get_pelanggan(),update_pelanggan(), get_laporan(), set_status()

3. Laporan cetak_laporan(),get_penjualan(), set_ststus()

Sumber: Penulis

g. Component Diagram

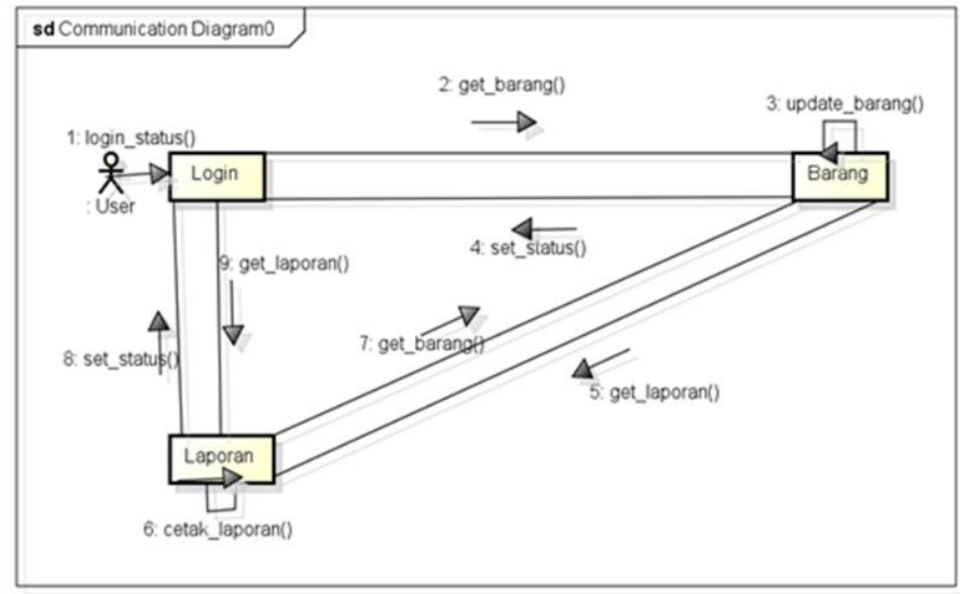

Gambar 11

Functional Component Diagram 
Perancangan Sistem Informasi Inventory dan Penjualan Menggunakan Visual Studio

h. Deployment Diagram

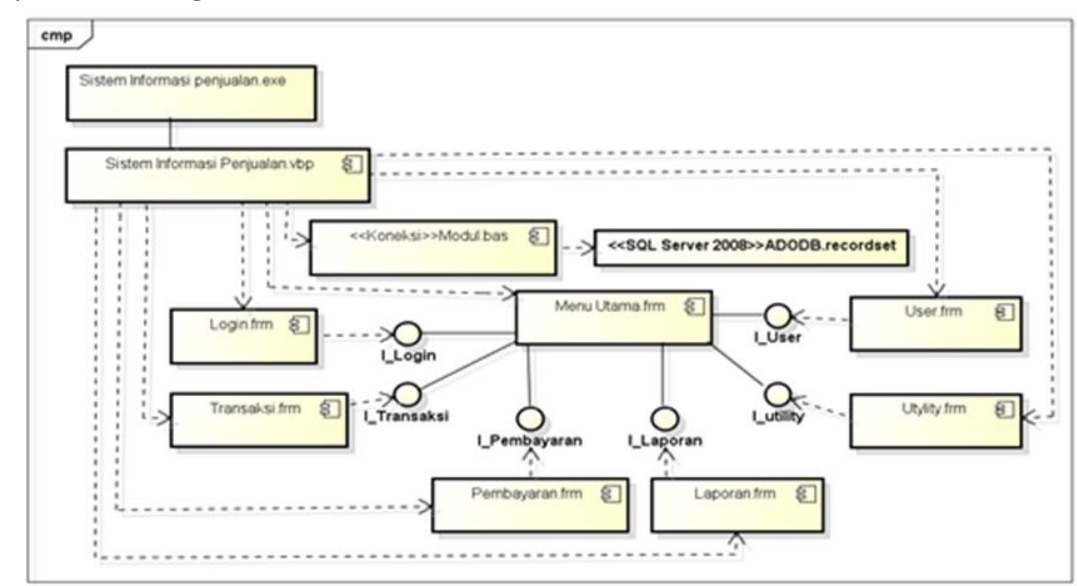

Gambar 12

Functional Componen Diagram

i. User Interface

a. Halaman Master Handphone dan Accessories

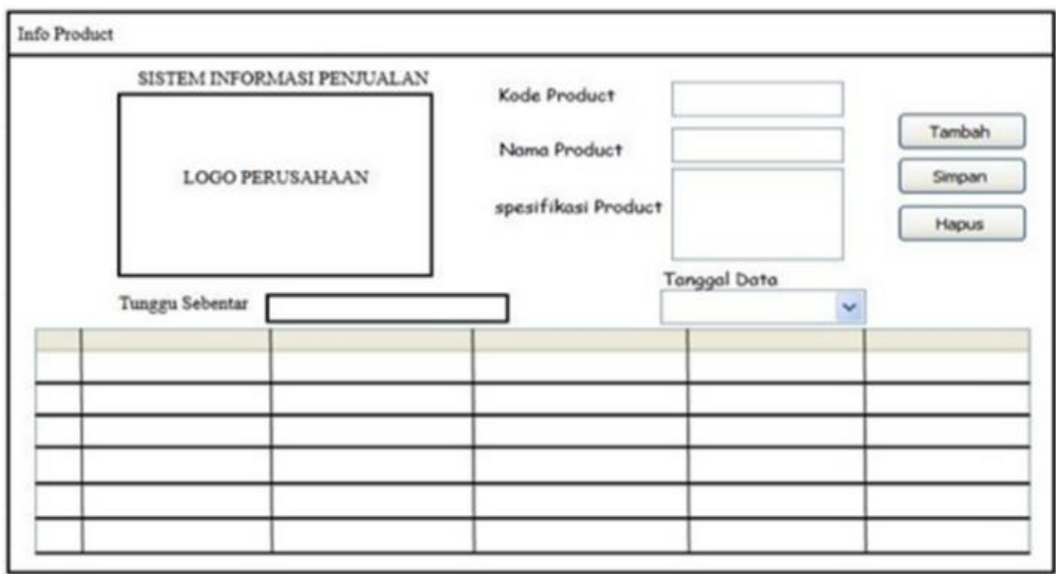

Gambar 13

Halaman Master Handphone dan Accessories

b. Halaman Biaya keperluan Toko

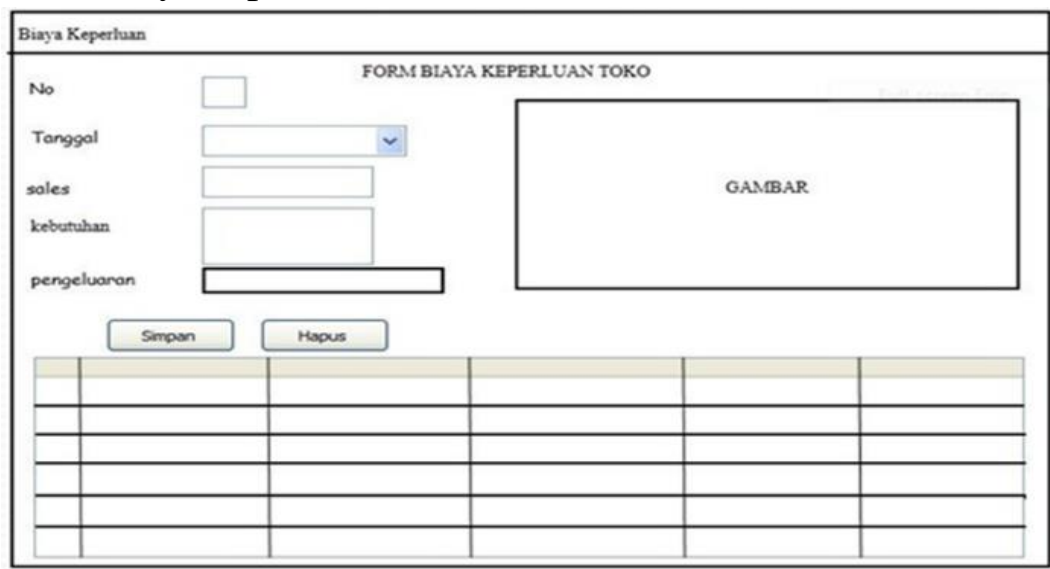

Gambar 14

Halaman Biaya Keperluan Toko 
c. Halaman Harga Jual

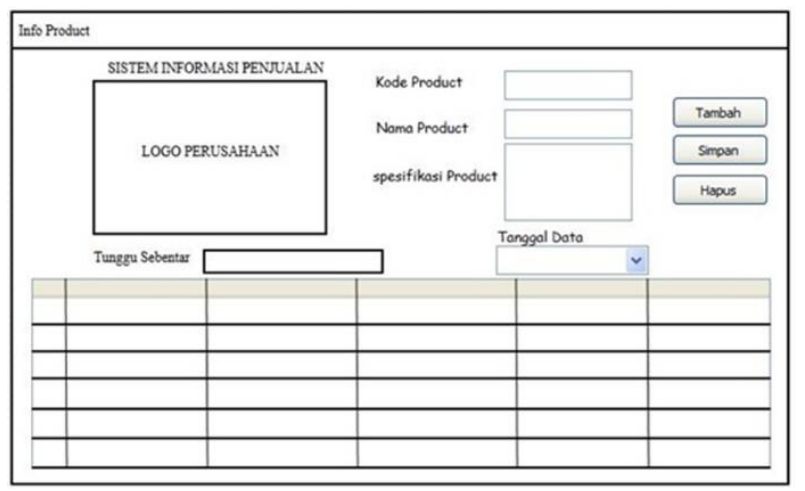

Gambar 15

Halaman Harga Jual

\section{Kesimpulan}

Dengan menggunakan aplikasi inventaris berbasis komputer untuk mengolah data dan menghasilkan laporan barang, pemrosesan barang, dan pelaporan barang dapat memperbaiki sistem yang sebelumnya seperti halnya dalam kegiatan transaksi yang biasanya harus memakan waktu yang lama tapi dengan adanya aplikasi ini semua akan berjalan lebih efektif dan efisien. Komputerisasi dalam hal ini merupakan alternatif solusi dari permasalahan dan dapat membantu menyelesaikan permasalahan yang dihadapi sistem lama. Karena kebutuhan untuk mencari data secara manual sulit bagi dukungan pusat data untuk menemukan data produk dengan cepat dan akurat. Karena sebagian besar dokumen merupakan arsip data manual mereka rentan terhadap kehilangan data. Dengan komputerisasi proses penyimpanan data dan pencarian data bisa lebih baik daripada sistem sebelumnya. 


\section{BIBLIOGRAFI}

Aggraeni, Dewi, Anandya, Dudi, \& Margaretha, Silvia. (2014). Keterkaitan Store Atmospheric, Joy Dan Customer Loyalty Pengunjung Trans Studio Bandung. Jurnal Manajemen Dan Kewirausahaan, 16(2), 163-174. Google Scholar

Boell, Sebastian K., \& Cecez-Kecmanovic, Dubravka. (2015). What Is An Information System? 2015 48th Hawaii International Conference On System Sciences, 49594968. Ieee. Google Scholar

Dharmawan, Krishna Duta, \& Sari, Wellia Shinta. (2016). Pembangunan Situs Web Menggunakan Metode Iconix Process Untuk Strategi Penjualan Komputer Pada CV. Citra Mandiri Semarang. Joins (Journal Of Information System), 1(2), 193-201. Google Scholar

Gata, Windu, \& Gata, Grace. (2013). Sukses Membangun Aplikasi Penjualan Dengan Java. Jakarta: Elex Media Komputindo. Google Scholar

Irsyad, Muhammad. (2014). Pengembangan Panduan Manajemen Perubahan Terhadap Keamanan Data Perusahaan. Jurnal Sains, Teknologi Dan Industri, 10(1), 36-41. Google Scholar

Laila, Nur. (2011). Sistem Informasi Pengolahan Data Inventory Pada Toko Buku Studi CV. Aneka Ilmu Semarang. Jurnal Teknik Elektro, 3(1), 40-55. Google Scholar

Lubis, Adyanata. (2016). Basis Data Dasar. Yogyakarta: Deepublish. Google Scholar

Noviandi, Budi Mochamad, Fatimah, Dini Destiani Siti, \& Partono, Partono. (2012). Perancangan Sistem Informasi Inventori Barang Di Bank Sampah Garut. Jurnal Algoritma, 9(2), 266-278. Google Scholar

Ramdhany, Tri, \& Kurnia, Deni. (2016). Perancangan Sistem Informasi Persediaan Barang Dagang Di PT Dimarco Mitra Utama Cabang Bandung. Jurnal Rekayasa Sistem \& Industri (Jrsi), 3(01), 19-26. Google Scholar

Roger, S. Pressman, \& Bruce, R. Maxin. (2015). Software Engineering: A Practitioner's Approach. Dearborn: Mcgraw-Hill Education. Google Scholar

Rossa, Arani Sukamto, \& Shalahuddin, Muhammad. (2013). Rekayasa Perangkat Lunak. Bandung: Penerbit Informatika. Google Scholar

Simarmata, Janner, Chaerul, Muhammad, Mukti, Retno Cahya, Purba, Deddy Wahyudin, Tamrin, Andi Febriana, Jamaludin, Jamaludin, Suhelayanti, Suhelayanti, Watrianthos, Ronal, Sahabuddin, Andi Arfan, \& Meganingratna, Andi. (2020). Teknologi Informasi: Aplikasi Dan Penerapannya. Medan: Yayasan Kita Menulis. Google Scholar

Solichin, Achmad. (2010). Mysql5: Dari Pemula Hingga Mahir. Jakarta: Achmad 
Asep Ramdhany, Dena Irawan

Solichin. Google Scholar

Tohari, Hamim. (2017). Astah-Analisis Serta Perancangan Sistem Informasi Melalui Pendekatan UML. Yogyakarta: Andi Offset. Google Scholar

Uslamarta, Zaiva Valevi. (2019). Perancangan Aplikasi Data Siswa Sma Pertiwi 1 Padang Menggunakan Bahasa Pemrograman Java Netbeans 7.1. 1. Jurnal Sains Dan Teknologi: Jurnal Keilmuan Dan Aplikasi Teknologi Industri, 19(1), 11-15. Google Scholar

\section{Copyright holder:}

Asep Ramdhany, Dena Irawan (2021)

First publication right:

Syntax Literate: Jurnal Ilmiah Indonesia

This article is licensed under:

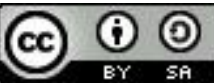

